\title{
Engagerende didaktiske design i blendede læringsrum - et grundlag for facilitering af læreprocesser
}

\section{Susanne Dau}

Docent og Programleder, Ph.d. Susanne Dau er docent og programleder for forkningsprogrammet Professionsudvikling \& Uddannelsesforskning ved UCN, Forsknings- og Udviklingsafdelingen. Susanne er særligt optaget af blended learning og ikt i professionsuddannelser i relation til udviklingen af studerendes professionskompetencer og herunder den professionelle dømmekraft.

\section{Ulla Konnerup}

Adjunkt, Ph.d.

Ulla Konnerup er adjunkt ved Institut for Kommunikation \& Psykologi på Aalborg Universitet. Hun er tilknyttet forskningscenteret e-Learning Lab - center for brugerdrevet innovation, læring og design. Ulla er særligt interesseret i virtuel læring og ikt-medieret didaktik, samt hvorledes ikt påvirker læring og identitetsdannelse. 


\section{Klik her for at angive tekst.Abstract}

Based on two case studies of Blended Learning (BL) courses in higher education; a university college education and a master's programme at a university, we will discuss the concept of Blended Learning. We distinguish between the teachers learning design and the students learning processes, where the teacher learning design includes planning, implementation and assessment, and learning includes a mental and/or an embodied change or development. We introduce a learning ecological thinking where entities in the virtual and physical environments motivate different activities. The research question addressed is; which learning design of Blended Learning encourages student involvement in the learning process, and what influence does the community in physical and online environments have for the commitment among the participants? The two cases reveal how educational design must necessarily facilitate the establishment of binding communities through the students' engagement.

\section{Abstrakt}

Med udgangspunkt i to cases, fra henholdsvis et forløb fra en professionsuddannelse og et forløb fra en masteruddannelse i ikt og læring, begge designet som Blended Learning, adresserer vi den retoriske problematik, der ligger i begrebet BL. Vi skelner mellem didaktik og læring, hvor didaktik forstås som undervisningstilrettelæggelse, gennemførelse og evaluering, og læring forstås som en proces, der involverer en mental og/eller kropslig ændring afhængig af samspillet med det omgivende fysiske og sociale læringsrum. Dermed lægges op til en læringsøkologisk tænkning, hvor entiteter i de virtuelle og fysiske miljøer motiverer til forskellige aktiviteter. Forskningsspørgsmålet som stilles er: Hvilke didaktiske design i de blendede læringsmiljøer motiverer studerendes engagement, og hvad betyder fællesskabet i fysiske og virtuelle miljøer for dette engagement? De to cases afslører, hvorledes didaktisk design nødvendigvis må facilitere etableringen af forpligtende fællesskaber, gennem de studerendes engagement.

\section{Introduktion}

Begreberne didaktik og læring er gennem de senere år i stigende grad blevet anvendt som to sider af samme sag uden klar distinktion. Et eksempel på denne begrebsmæssige sproglige forvikling er begrebet BL, der grundlæggende er et didaktisk begreb for rammesætningen af undervisningen, typisk en kombination af fysisk tilstedeværelses- og virtuel undervisning. Retorisk er begrebet dog knyttet til læringsbegrebet. På samme måde er begrebet læringsdesign afledt af det engelske learning design. Læringsdesign retter sig mod undervisningstilrettelæggelse, hvilket kunne argumentere for på dansk at kalde det didaktisk design i stedet. I denne artikel anvendes didaktik og didaktisk som en samlet betegnelse for teori og praksis, en teoretisk videnskab om undervisning og en kritisk / humanistisk forståelse 
af undervisningen som underviserens praksis. Med andre ord er det underviseren, der med udgangspunkt i en læringsforståelse/teori tilrettelægger, gennemfører, og evaluerer sin undervisning under hensyntagen til målgruppens forudsætninger, konkrete rammefaktorer, pædagogiske metoder, mål, midler og indhold (Hiim \& Hippe, 2007). Såvel rammefaktorer og metoder indbefatter læringsmiljø, læringsrum, teknologier og medier. Underviserne kan således betegnes som didaktiske designere, der designer undervisningsforløb. Vi skelner endvidere mellem læringsrum og læringsmiljø, hvor rum refererer til konkrete fysiske og online lokaliteter og læringsmiljø refererer til den samlede læringsøkologi.

Inddragelse af teknologimedierede og webbaserede læringsmiljøer har udfordret den traditionelle forståelse af didaktik og læring. It og ikke mindst internettet har på flere måder været katalysator for forandring inden for uddannelse og læring. Det emergerende felt "Learning Design" udspringer af et ønske om at bidrage med et deskriptivt sprog for helt eller delvist teknologimedieret undervisning og læring (Dalziel, 2003; Dalziel m.fl., 2016; Laurillard, 2008), ligesom diskussionen om det 21. århundredes kompetencer forholder sig til de nye læringsformer og design af uddannelse, der dels muliggøres af ny ikt, dels fordres af et moderne erhvervsliv (Borgmann, 2010; Gynther, 2014; Sharpe \& Beetham, 2010). BL gør mulighederne for livslang læring mere fleksible (Garrison \& Kanuka, 2004) og kan dermed tilbyde et didaktisk design, der understøtter løbende videnstilegnelse og udvikling i et konstant foranderligt samfund.

Ved uddannelses- og forskningsministerens tale ved uddannelsesmøde d. 28. april 2016 fremhævede Ulla Tørnæs, at kvalitet handler om, hvad den enkelte studerende lærer og får ud af deres studie. Endvidere sagde hun:

"Og vi ved, at der er en sammenhæng mellem studieaktivitet, og hvad den studerende får ud af sit studie. Jo større indsats og engagement, des højere udbytte." (Tørnæs, 2016).

Det bliver derfor aktuelt at undersøge, hvorledes designet af BL forløb på forskellige uddannelser kan bidrage til studerendes engagement, hvilket også er ærindet med herværende artikel. I OECD's (2016) rapport 'An OECD Horizon Scan of Megatrends and Technolology trends in the Context of Future Research Policy' beskrives, hvilke udfordringer forskningen og samfundet fremadrettet må adressere. Her er der et dominerende fokus på den digitale udvikling og de muligheder og udfordringer, dette giver i relation til uddannelse. BL og e-læringsforløb kan gennem den fleksible tilrettelæggelse og inddragelsen af nye teknologier være et relevant bud på nogle af disse udfordringer til at kvalificere studerende til et fremtidigt samfund og samtidigt facilitere deres kompetencer til kontinuerlig professionel udvikling og læring. Hvorledes designes læring og undervisningsforløb, der på én gang imødeser samfundets krav, studerendes behov for fleksibilitet i tid og rum og 
samtidig inddrager digital teknologi? Hvad skal underviserne, her forstået som didaktiske designere, medtænke i nye fleksible læringsforløb? I denne artikel vi vil have fokus på engagement og fællesskab, idet engageret deltagelse spiller en central rolle i kritisk- humanistiske didaktiske positioner. Eksempelvis pointerer Hiim \& Hippe (2007 s. 205) vigtigheden i, at læringsindholdet appellerer til fantasi, åben problemløsning og engagement, ligesom et af principperne i Aalborg Universitets Problem Baseret Læring (PBL) er gruppebaseret studenterengagement i projektarbejde (Kolmos, Fink, \& Krogh, 2004, s. 12 ff.). Endeligt tilskriver Illeris (2011) engagement hos den lærende en afgørende rolle for, at der kan finde en egentlig kompetenceudvikling sted. De mangeartede og mangefacetterede læringskontekster både virtuelt og fysisk, formelt og uformelt udfordrer didaktiske designere, og det bliver nødvendigt at forholde sig til, hvordan læring finder sted i og på tværs af forskellige typer af læringsmiljøer. Dette og de nævnte forudsætninger for læring vil blive udfoldet i besvarelsen af artiklens forskningsspørgsmål, som undersøger, hvilke didaktiske design i de blendede læringsrum, der motiverer studerendes engagement i læreprocessen, og hvad fællesskabet i fysiske og virtuelle miljøer betyder for dette engagement?

Artiklen tager sit metodiske udgangspunkt i en kvalitativ hermeneutiskfænomenologisk undersøgelsestilgang med udgangspunkt i casestudier omhandlende fysiske og virtuelle miljøer.

Læringsmiljøerne i artiklens tre cases finder sted, delvis i virtuelle miljøer og ved klassisk fysiske undervisningsaktiviteter. Undervisningsudbyderne kalder dem for blendede læringsforløb. Vi forholder os kritiske til begrebet, da det ikke er selve læringen, der redegøres for i teorierne, men undervisningstilrettelæggelsen i fysiske og virtuelle miljøer.

Vi finder begrebet, Learning Ecology, blandt andet beskrevet af Barron (2004), mere dækkende for den praksis, der finder sted i uddannelserne. Hun definerer learning ecology således:

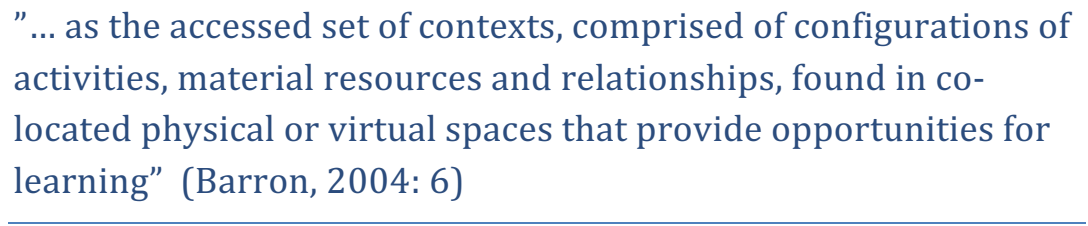

"Begrebet Learning Ecology refererer altså til en samling af virtuelle og fysiske kontekster/miljøer, der faciliterer læring. Begrebet bidrager til at forskellige kontekster og teknologier forstås som en helhed indlejret i de lærendes samlede liv og erfaringer.

Det erkendelsesteoretiske forståelsesgrundlag, som denne artikel tager udgangspunkt i bliver dermed en læringsøkologisk forståelse, med fokus både 
på individets samspil med omgivelserne, entiteter og andre individer. Læring bliver et anliggende, hvor viden konstrueres og genereres i samspil med fagfæller og det omgivende miljø. Denne forståelse af læring er overvejende situeret og procedural og understøttes af, at viden tages i anvendelse med de ressourcer, som miljøet og fællesskabet faciliterer.

\section{Casestudier}

Ovenstående komplekse helhed af aktioner og interaktioner søges i det følgende belyst gennem 3 casestudier.

Casestudier er velegnede til at indfange erfaringer og sociale processer (Launsø, Rieper, \& Olsen, 2011) og dermed også de dele af forskningsspørgsmålet, der vedrører fællesskabet og designprocessernes betydning for engagement.

Der er valgt 3 cases fra professionsfeltet, de 2 af casene vedrører grunduddannelserne til 2 forskellige professioner henholdsvis lærer og radiograf, og den 3. case vedrører efter-videreuddannelsen master i ikt og læring (MIL). Denne selektion er foretaget, for at få både en bred repræsentation af voksenstuderende på forskellige uddannelsesniveauer og med forskellige fagligheder. Casene fremstår som en overordnet rammefortælling, og efterfølges af analyser, centreret omkring empirinært udledte temaer, der omhandler studerendes oplevelser af engagerende designs i virtuelle og fysiske miljøer.

\section{Datagrundlag}

Datagrundlaget består af en række fokusgruppeinterviews.

Fokusgruppeinterview er velegnede til at indfange empiriske data, der kan belyse betydningsdannelsen i grupper og medvirke til en kognitiv genindramning af mening hos de studerende. Fokusgruppeinterviewene blev strukturerede omkring oplevelsen af designet, læringen i de blendede forløb og læringsmiljøet. Der blev valgt semistrukturerede og åbne spørgsmål, da de lægger op til at informanterne kan fortælle frit om deres liv indenfor det overordnede emne, BL. Ved de opfølgende spørgsmål blev anvendt hv.-ord og udvidede, opklarende eller verificerende gensvar. En oversigt over fokusgruppeinterviewene fremgå af figur 1 nedenfor: 


\begin{tabular}{|l|l|l|l|l|}
\hline Informanter & Dato & Antal & sted & varighed \\
\hline $\begin{array}{l}\text { Radiografstuderende } \\
\text { (RS) }\end{array}$ & 04.12 .2012 & $\begin{array}{l}6(2 \text { mænd,4 } \\
\text { kvinder) }\end{array}$ & UCN & 1 time \\
\cline { 2 - 5 } & 08.09 .2013 & $\begin{array}{l}6(1 \text { mand, 5 } \\
\text { kvinder) }\end{array}$ & UCN & 1 time \\
\cline { 2 - 5 } & 09.09 .2014 & 2 (2 kvinder) & UCN & $1 / 2$ time \\
\hline \multirow{3}{*}{$\begin{array}{l}\text { Lærerstuderende } \\
\text { (LS) }\end{array}$} & 27.11 .2012 & $\begin{array}{l}8 \text { (1 mand, 7 } \\
\text { kvinder) }\end{array}$ & UCN & $\begin{array}{l}1 \text { time og 15 } \\
\text { minutter }\end{array}$ \\
\cline { 2 - 5 } & 02.09 .2013 & 4 (alle kvinder) & UCN & $11 / 2$ time \\
\cline { 2 - 5 } & 23.04 .2014 & 5 (alle kvinder) & UCN & 1 time \\
\hline \multirow{2}{*}{$\begin{array}{l}\text { Masterstuderende } \\
\text { (MS) }\end{array}$} & 16.06 .2014 & 2 (mænd) & AAU & 1 time \\
\hline
\end{tabular}

Figur 1 Oversigt over fokusgruppeinterviews

I alle fokusgruppeinterview har grundlaget for fokusgruppeinterviewene været forskernes kendskab til feltet, som har været en forudsætning for at kunne skabe rum for tillid og fortællinger. Der har været etiske overvejelser over: Sammensætning af gruppen af informanter, åbenhed om form og indhold, indhentelse af informeret samtykke og sikring af tavshedspligt overfor personhenførbare data. Derudover har der været fokus på retfærdighed, anerkendelse og legitimering af divergerende meninger samt sikring af respekt og ligeværdighed. Der er løbende blevet samlet op på informanternes meningsdannelse gennem verificering af forståelser og korrekt gengivelse af data i sin sammenhæng.

I herværende artikel præsenteres først de 3 cases. Dernæst er de empiriske data hentet fra alle cases og kategoriseret omkring centrale temaer. Inden casene fremstilles, redegøres der for den teoretiske ramme omkring BL.

\section{Blended Learning}

BL indskriver sig i en e-læringsforståelse, der epistemologisk baserer sig på socialkonstruktivistiske og erfaringsbaserede læringsformer, hvilket implicerer læring i netværk og praksisfællesskaber, og kan resulterer i nedbrud af grænserne mellem formel og uformel læring (Ryberg \& Dau, 2013). Selve ordet læring i blended læring refererer ikke direkte til læringsprocessen, men til en didaktisk rammesætning af en kombination af fysiske og virtuelle undervisningsmiljøer (Oliver \& Trigwell, 2005).

Hensigten i denne artikel er derfor at se på de oplevelser og erfaringer, som studerende har gjort sig som lærende under de blendede didaktiske design. 
Der har i det seneste årti været en stadig større udbredelse af BL både på universiteter og University Colleges, og BL defineres typisk som en integration af nøje udvalgte og komplementære ansigt-til-ansigt aktiviteter, virtuelle tilgange og teknologier (Garrison \& Vaughan, 2008, p. 148). Formen anses for at bidrage til en pædagogisk mangfoldighed, at øge adgangen til viden og social interaktion, samt muligheder for individuel tilrettelæggelse, økonomisk effektivitet og hurtig revision (Graham, 2006). Dette er elementer, som alle kan bidrage til et øget engagement hos deltagerne. Engagementets betydning for BL, og successen hermed, er beskrevet i flere videnskabelige undersøgelser. I Florers Ph.d. afhandling (2013) redegøres der f.eks. for, hvorledes studerendes engagementer er en forudsætning for brugen af teknologier i BL. I andre Ph.d.-afhandlinger vises, at engagementet i BL forløb er under indflydelse af de studerendes følelser og kropslige adfærd, samt af deres refleksioner og sociale interaktioner (Dau, 2015; Piki, 2011). Herudover er studerendes engagement afhængig af undervisernes feedback (Kemp, 2013) og deres engagement i tilrettelæggelsen af BL (Jokinen \& Mikkonen, 2013). Fællesskabet har endvidere betydning for studerendes engagement og faglig identitetsdannelse i sådanne forløb (Kemp, 2013; Masika \& Jones, 2016).

Et centralt element i relation til BL er læringsrummene og hvordan de studerende orienterer sig fysisk og mentalt her indenfor. Wozniak, Lever \& Pizzica (2009) udleder 3 dimensioner af betydning for studerendes orientering; en refleksionsdimension, en interpersonel dimension og en teknologisk dimension. Refleksionsdimensionen vedrører selvregulering og kritisk refleksion, den interpersonelle dimension omhandler udvikling af sociale netværk, og den teknologiske dimension fungerer både som en mulighed og en barriere i transitionen mellem hverdagsliv og akademisk uddannelse. De 3 dimensioner genfindes i en dansk undersøgelse af studerendes orentering i BL læringsrum. Denne undersøgelse viser også at den væsentligste faktor for engagementet og orienteringen i BL er de sociale relationer (Dau, 2015).

\section{State of the Art}

Forskning relateret til radiograf- og læreruddannelserne peger på flere muligheder i brugen af BL. F.eks. viser en spørgeskemaundersøgelse af hollandske lærerstuderende, udarbejdet af Matzat (2013), at lærerstuderende profiterer af tilknytningen til sociale ansigt-til-ansigt fællesskaber i deres professionelle vidensudvikling. Undersøgelsen viser, at jo højere grad af sociale relationer, der er mellem studerende (også virtuelt), jo bedre bliver studerendes undervisningsfærdigheder. Derudover viser undersøgelsen, at jo flere digitale kompetencer, de studerende har, jo større læringsudbytte har de af undervisningen (Matzat., 2013).

I forhold til radiografuddannelser så peger et pilotstudie af 1. og 2. års radiografstuderende på, at praksisnær undervisning i integrerede blendede 
forløb er velegnet pædagogisk rammesætning. Der er dog andre forskningsresultater, der afslører væsentlige barrierer i brugen af BL for både studerende og undervisere indenfor radiografuddannelserne, f.eks. kan der være problemer med adgang til og navigation i de virtuelle læringsmiljøerne (John-Matthews, Gibbs, \& Messer, 2013; Dau 2015).

I relation til masteruddannelserne foreligger der også flere undersøgelser. En afdækning af masterstuderende læreres deltagelse i blendede forløb har f.eks. vist, at masterstuderende opnåede læringserfaringer og kompetencer, som de kunne anvende i egen underviservirksomhed til at styrke deres elevers læring (Motteram, 2006). Tilsvarende viste en undersøgelse, af lærere på eftervidereuddannelse, at BL og brugen af formative læringstilgange øger lærernes kompetence til deltagelse, kollaboration og refleksion og bidrager med, at de som undervisere kan facilitere deres egne studerendes kompetencer til livslang læring (Santandreu Calonge, Chiu, Thadani, Mark, \& Pun, 2011). En undersøgelse af masteruddannelser i Irland foretaget blandt sygeplejersker og jordmødre (3000 informanter) viste, at de studerende vurderer tilgængeligheden og fleksibiliteten som altafgørende. Omvendt viste det sig også, at det kunne være svært at få studie og privatliv til at hænge sammen, og at de studerende savnede feedback og social interaktion. Undersøgelsen konkluderede, at der er brug for at skærpe den socialkonstruktivistiske tilgang i blendede læringsforløb (Smyth, Houghton, Cooney, \& Casey, 2012).

I forhold til det overordnede design af BL, så peger empiriske studier på væsentlige aspekter, som bør medtænkes, når ikt er en del af undervisningsdesignet: 1 ) underviser og studerendes roller og 2) indflydelse og kontrol af didaktisk anvendelse af teknologi; herunder motivationen, infrastrukturen og ressourcerne (Glud, Buus, Ryberg, Georgsen, \& Davidsen, 2010). Hvad angår det didaktiske design, så har Chew, Jones \& Turner (2008) foretaget et kritisk review af 4 overordnede modeller for BL. De finder, at enhver implementering af modeller for BL nødvendigvis må medtænke pædagogisk teori og pointerer, at læringsomgivelsernes sociale interaktioner, kommunikation og kultur er en essentiel del i designet af BL.

Kollaborative læreprocesser og læringsøkologiske perspektiver udgør også"en central kerne i udvidelse af læringsforståelsen inden for BL. Det handler om, læring ikke kun vedrører individets egen videnstilegnelse og faglige indsigt, men også indgår i en større kompleksitet, hvor fagfæller, vidensnetværk og omgivelser har væsentligt betydning (Rennie \& Morrison, 2013, kap. 1). Kun få forskere har adresseret et mere læringsøkologisk perspektiv på design. I en dansk kontekst har Dau (2015) senest adresseret denne tilgang, og fundet, at dimensionerne socialitet, interaktionalitet, og identitet er relevante at medtænke i et økologisk funderet design. Der mangler dog stadig konkrete svar på, hvad det er for didaktiske designs indenfor BL, der kan motivere studerendes engagement i læreprocessen, og hvilken betydning fællesskabet har herfor. 


\section{Didaktisk design i praksis}

Ikt-medierede læringsaktiviteter garanterer ikke i sig selv kvalitet og konstruktive læreprocesser. Zemsky og Massy (2005, s. 248) diskuterer en risiko for at reducere læringsudbyttet hos den studerende, hvis eksisterende læringsaktiviteter overføres til e-læring uden remediering. For at imødegå en sådan risiko og en tendens til behavioristisk instruktivistisk didaktik inden for e-læring har bl.a. Laurillard $(2008,2013)$ og Harasim (2012) beskrevet, hvordan digital teknologi kan være en katalysator for redesign og innovative læringsformer. Som nævnt er vores brug af didaktisk design afledt af det emergerende begreb Learning Design. Learning Design har ligeledes til hensigt at udvikle en beskrivende ramme for undervisnings- og læringsaktiviteter, der kan muliggøre deling af praksis mellem undervisere. Deskriptive didaktiske design og videndelingen herom er et centralt element til at kvalificere undervisning og læring, så denne samsvarer til kravene om brug af digital teknologi, multitasking, kollaboration, vidensanvendelse i stedet for vidensassimilation (Dalziel et al., 2016). Tankerne bag Learning Design (her forstået som didaktisk design) er beskrevet i Larnaca Deklarationen (Dalziel et al., 2016)og giver en overordnet ramme til beskrivelse af didaktiske design (figur 2).

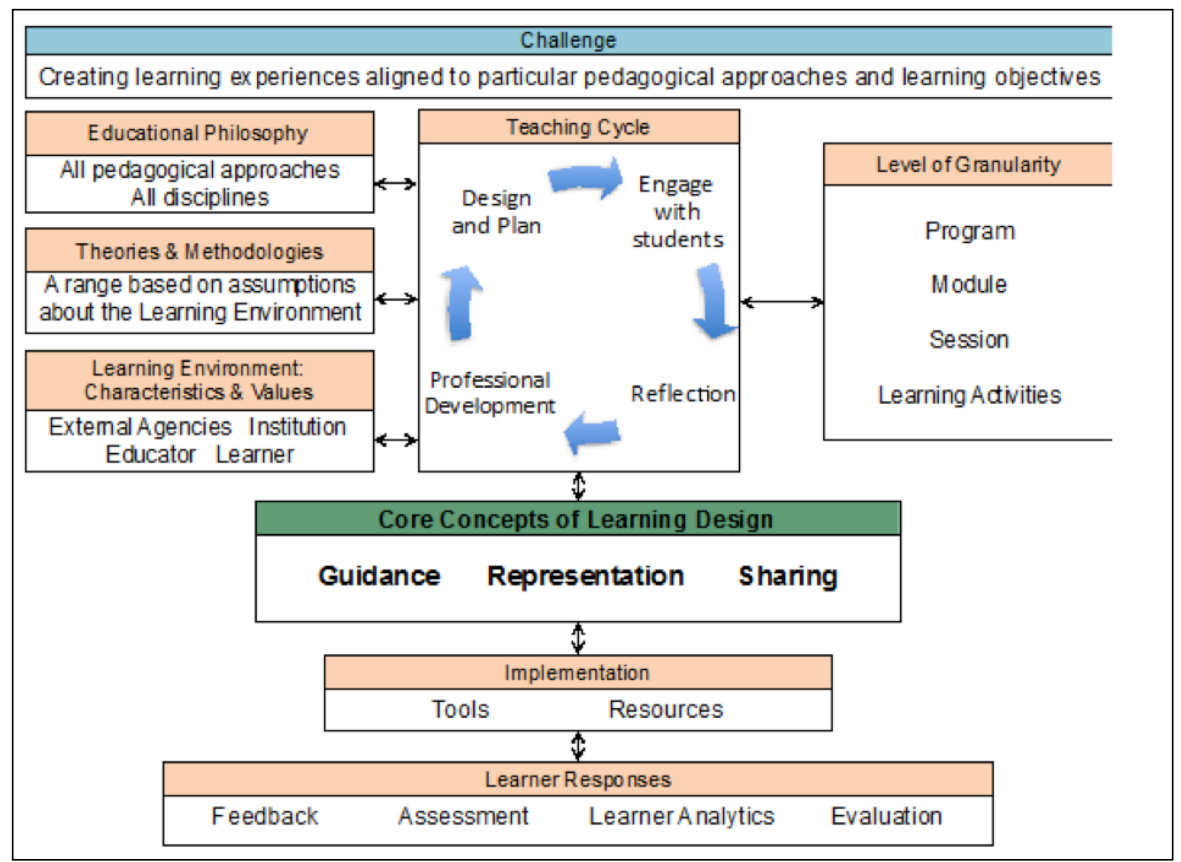

Figur 2 Et begrebsligt kort til Learning Design (Dalziel et al., 2016)

Figur 2 illustrerer, hvorledes didaktisk design som udgangspunkt tager afsæt i en udfordring, hvorunder der indgår grundlæggende antagelser, altså en undervisningsfilosofi, bestemte metoder og teorier, som danner grundlag for designet og konkrete læringsmiljøer. Disse antagelser har indflydelse på undervisningens cyklus (fig. 2), herunder designet, samspillet med studerende, refleksioner og den professionelles udvikling. Undervisningen er også rammesat af de konkrete moduler/semestre, læringsmål og herunder 
studieordninger og bekendtgørelser. Disse overordnede elementer spiller ind på kernebegreberne i det didaktiske design. Designet er dermed under indflydelse af de værktøjer og ressourcer, som er tilstede i situationen, men derudover også af de lærendes ressourcer, herunder feedback, vurdering, samt den lærendes analyse og evaluering. Det begrebslige kort over læringsdesign (didaktisk design) fremsat i Larnaca Deklarationen giver således en overordnet reflektorisk ramme for beskrivelse af design og konkrete elementer, der bør medtænkes i udarbejdelsen af sådanne. Rammen er anvendelig for beskrivelsen af design indenfor BL. I de følgende cases vil elementer fra figur 2 blive inddraget i beskrivelsen af de didaktiske designs, som relaterer sig til casene.

Dalziel et al.'s model begrebssætter ikke direkte fællesskabet indenfor professioner, professionsuddannelser og masteruddannelser samt eftervidereuddannelser, selvom der ligger elementer heraf indenfor kernebegreberne af Learning Design. Forskning peger dog på, at Learning Design/didaktisk design har nogle overordnede implikationer: 1) bør fokuser på relationer 2) skal understøtte meningsfuld social interaktion og 3) virtuelle fora og sociale fora skal facilitere og give et rum for tryg identitetsdannelse (Henderson, 2007)

Den anvendte metode ved casestudierne og analyserne heraf vil blive beskrevet i metodeafsnittet nedenfor.

\section{Cases}

\section{Case for professionsuddannelsen til lærer og radiograf}

I perioden 2012-2014 blev BL implementeret i lærer- og radiografuddannelsen på University College Nordjylland (UCN). Læreruddannelsen havde ikke tidligere arbejdet med BL, men havde erfaringer med rene virtuelle forløb fra meritlæreruddannelsen.

Radiografuddannelsen havde arbejdet med den fleksible tilrettelæggelse af undervisningen gennem fysiske og virtuelle forløb siden 2008 og havde som følge heraf en del erfaringer med blendede undervisningsforløb. Begge uddannelser begyndte officielt på implementeringen af blendede forløb i 2012 under projektet FlexVid. Begge uddannelser havde en struktur hvor ca. 50 \% af undervisnings-/studietiden pågik udenfor campus. Der var henholdsvis 32 lærerstuderende (LS) og 27 radiografstuderende (RS). Uddannelserne anvendte læringsplatformen It's Learning og gjorde brug af web 2.0 teknologier, Camtasia, videopræsentation og Adobe Connect videokonference i relation til de virtuelle forløb. Ligeledes var gruppedannelse centralt for begge uddannelser, da sociale relationer blev prioriteret som et væsentlig grundlag for læring. Det didaktiske design for de blendede uddannelser er angivet i figur 3 nedenfor, denne model er inspireret af Larnaca Learning Design (Dalziel et al., (2016) og projektlederen (Staugaard, 2012). 


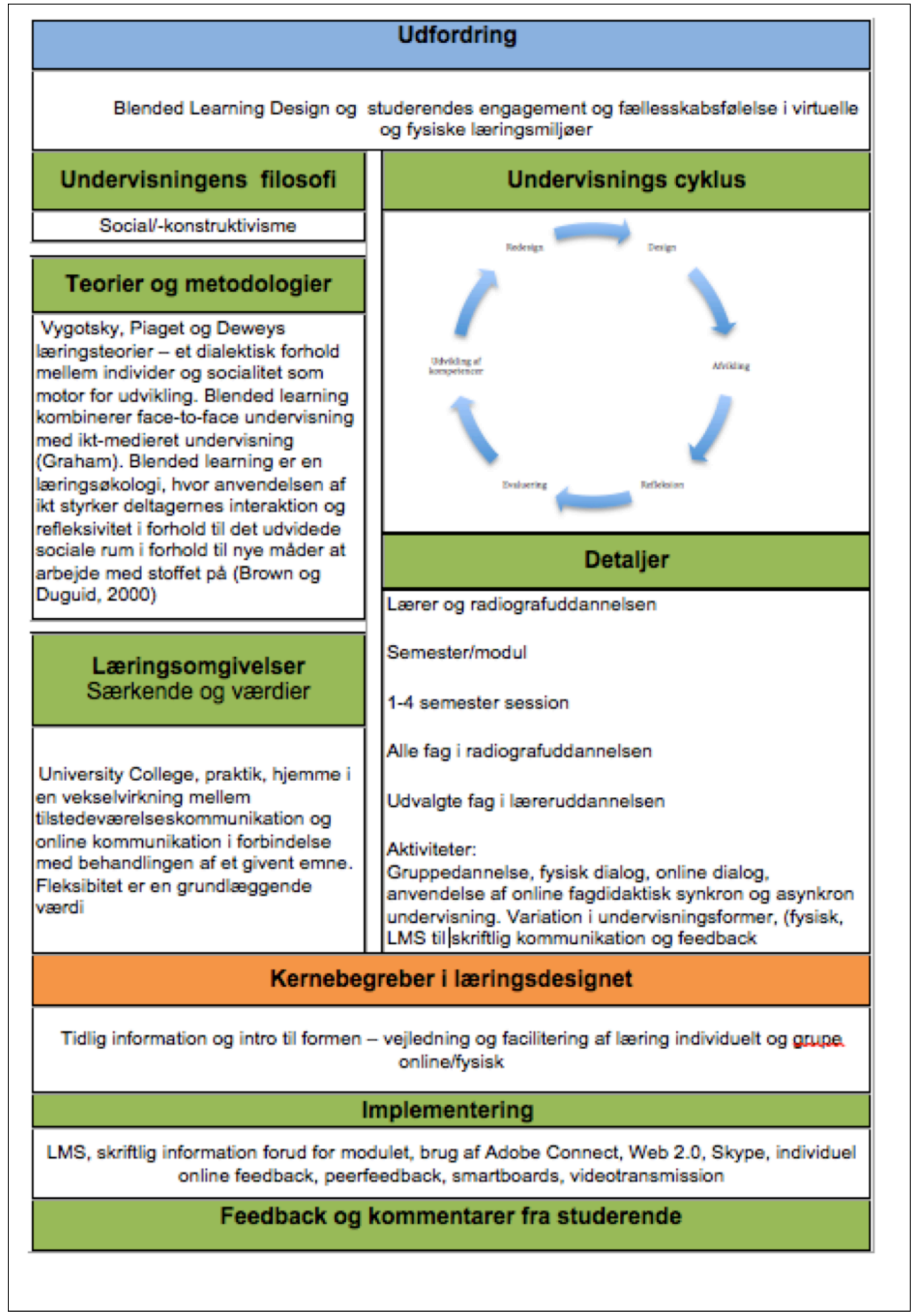

Figur 3: Et begrebsligt kort til det didaktiske design i lærer- og radiografuddannelsen 


\section{Læreruddannelsen som case}

Begrundelsen for at arbejde med BL i læreruddannelsen var baseret på en antagelse om pædagogisk merværdi, øget tilgængelighed og fleksibilitet, undervisningsdifferentiering og øget professionsrettethed. Målet var at kvalificere studiegruppearbejdet, at skabe sammenhæng og synergi mellem fagene. Derudover ønskede man at skabe større evne til refleksion over egen læring gennem ikt-baserede studieværktøjer, herunder gennem kommunikation med medstuderende, undervisere, forskere og praktikere(Christensen \& Kristensen, 2012).

BL blev i læreruddannelsen beskrevet, som et mix af forskellige læringsformer og teknologier. Intentionerne var at øge de studerendes studieaktiviteter udenfor campus i perioder, der ikke var skemalagte. Der blev i læreruddannelsen arbejdet med tilstedeværelsesundervisning og med virtuelle synkrone og asynkrone forløb.

Det didaktiske design blev beskrevet som en didaktisk blanding af formidling/selvstudier/studiegruppearbejder og kollaborativ læring. Den didaktiske tilrettelæggelse i læreruddannelsen vægtede proces- og projektorienteret studieformer, men også erfaringsbaseret og dialogorienterede undervisningsformer. I forhold til den virtuelle del af tilrettelæggelsen var der følgende hovedpunkter i læreruddannelsens emodel:

- Undervisning og vejledning af lokale studiegrupper virtuelt parallelt med studieforløb på professionshøjskolen

- Gennemførelse af tilstedeværelsesundervisning og -vejledning, samt undervisning og vejledning ved hjælp af it-støttet synkron og asynkron kommunikation

- Praktikken som omdrejningspunkt.

Dermed var der lagt op til, at e-læringsforløb kunne foregå på forskellige lokationer, i forskellige undervisningssammenhænge og synkront som asynkront. Det viste sig dog hurtigt, at den fysiske undervisning suppleret med asynkrone virtuelle ressourcer var langt mere engagerende end den synkrone undervisning, der var præget af afbrud, tekniske vanskeligheder, kommunikations- og koordinationsproblemer, dårlig lyd o.a. (Christensen \& Kristensen, 2012)

\section{Radiografuddannelsen som case}

De primære formål med at tilrettelægge moduler med BL i radiografuddannelsen var at støtte studerende i at nå deres læringsudbytte for aktuelle moduler gennem deltagelse i varierede undervisningsformer uden og med brug af it og derudover, at de anvendte deres studietid hensigtsmæssigt i forhold til at nå mål for aktuelt modul (Egekvist et al., 2012). Den didaktiske model var inspireret af Hiim og Hippe (2007). 
Radiografuddannelsen beskrev BL med udgangspunkt i deres pædagogiske fokus, som var på kommunikation og feedback. I lighed med læreruddannelsen blev synkrone og asynkrone virtuelle seancer tilrettelagt og forskellige virtuelle it-værktøjer blev anvendt. De virtuelle muligheder blev også inddraget i relation til praktikperioder, hvor studerende og kliniske vejledere kommunikerede virtuelt fra de forskellige sygehuslokationer. Alle underviserene kunne trække på tidligere viden og erfaringer i relation til tilrettelæggelsen af de blendede forløb.

I radiografuddannelsen blev alle moduler tilrettelagt ud fra følgende princip: Maksimum halvdelen af undervisningen i et fag eller tema måtte være tilrettelagt som fysisk tilstedeværelsesundervisning, og minimum halvdelen af undervisningen skulle være tilrettelagt med virtuel tilstedeværelse. Typisk bestod en uge af 2-3 online undervisningsdage og 2-3 analogt tilrettelagte dage.

Designet af de virtuelle forløb var inspireret af Rogers, Sharp \& Preece's (2011) idéer om, at systemerne bør indrettes, så de er brugervenlige. Designet indeholdte således overvejelser over:

- Udseende og fremtoning

- Organisering af data

- Funktionalitet

- Interaktivitet

- Spatial struktur

Designet var gennemgående i både fysiske og virtuelle miljøer (Egekvist et al., 2012).

\section{Master ikt og læring som case}

Masterprogrammet ikt og læring (MIL) er et eksisterende samarbejde mellem 4 universiteter i Danmark, Aarhus Universitet (AU), Roskilde Universitet (RUC), Aalborg Universitet (AAU) og Copenhagen Business School (CBS) og udbydes under IT-Vest. Initiativtagerne bag masterprogrammet var alle forskere tilknyttet det nationale forskernetværk Læring og Multimedier. MIL er et halvtids studie, der strækker sig over 2 år til 60 ECTS point. Det overordnede genstandsfelt er teoretiske, analytiske, metodiske og designmæssige perspektiver på forholdet mellem ikt og læring, med fokus på udvikling og ændrede praksisformer som ikt-medieret læring og undervisning skaber i skole, hverdag og arbejdsliv.

MILs Learning Design er her lagt ind i Larnaca Declarations forlag for en deskriptiv ramme, se figur 4 nedenfor. 


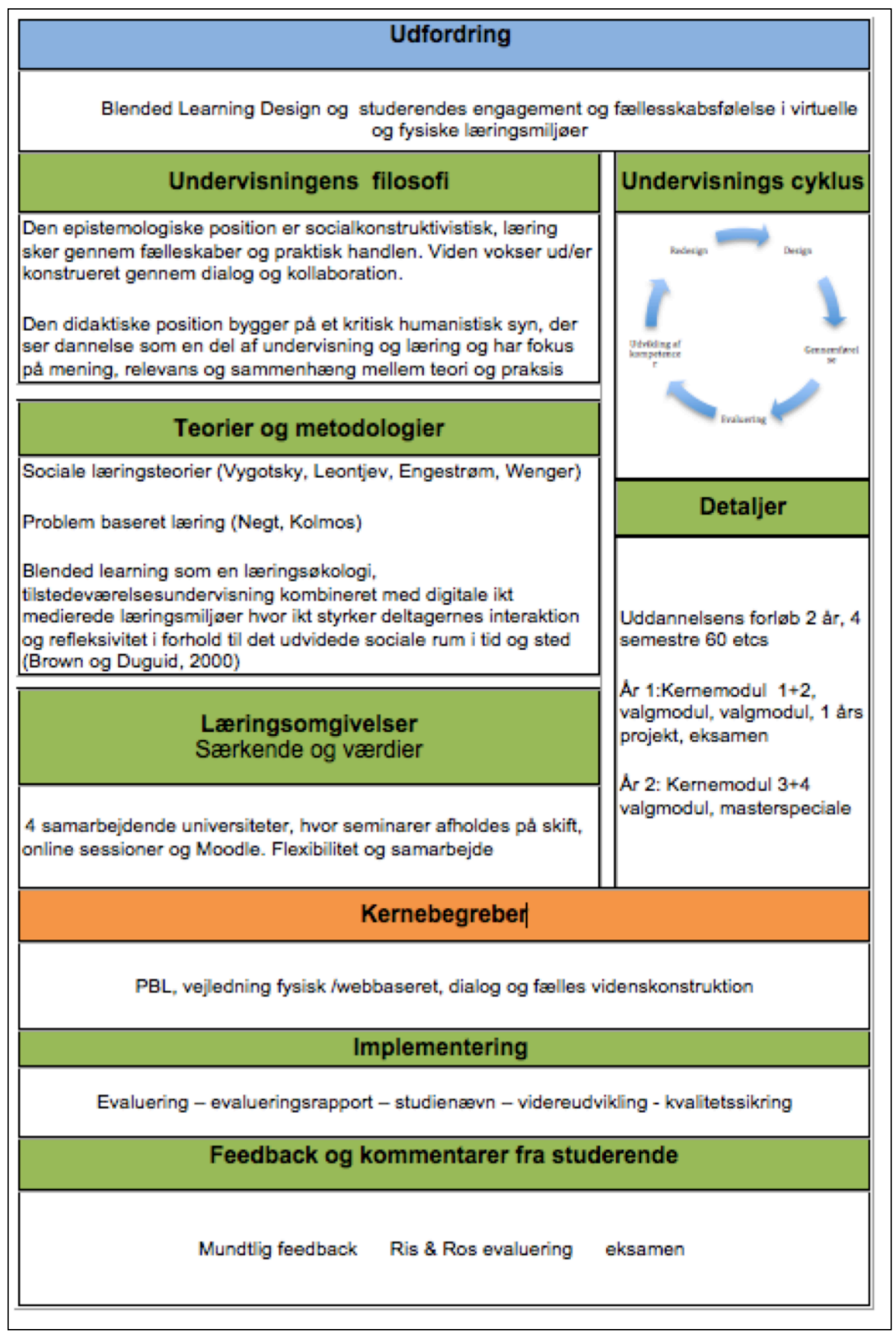

Figur 4. Et begrebsligt kort til det didaktiske design i MIL uddannelsen

De studerende kommer fra hele Danmark, enkelte fra øvrige nordiske lande. Målgruppen er personer, der interesserer sig for integration af ikt $\mathrm{i}$ læreprocesser, f.eks. undervisere, planlæggere, uddannelsesansvarlige for implementeringen af ikt i udvikling af "Human Resources" i organisationer og virksomheder, eller softwareudviklere og designere af ikt produkter og virtuelle læringsomgivelser ('Master i IKT og Læring', 2016) Adgangskrav er, at ansøgerne allerede har en bachelor samt mindst 2 års erhvervserfaring indenfor et relevant område. De studerende får gennem studiet mulighed for at udvikle og integrere ikt-baserede læreprocesser i praksis, deltage i 
eksperimentel og brugerorienteret udvikling af ikt samt forstå konsekvenser og muligheder af ikt-baserede læringssystemer.

Uddannelsen betegner sin rammesætning som blended i den forståelse, at aktiviteterne finder sted såvel ved fysiske seminarer (3 gange årligt) som via digitale værktøjer og læringsmiljøer (Andreasen \& Nielsen, 2013) og placerer sig læringsmæssigt inden for traditionen Networked Learning (NL). I MIL sammenhæng refererer NL både til det at være forbundet via digitale teknologier og til det at arbejde kollaborativt i projektarbejde (Andreasen \& Nielsen, 2013).

Uddannelsen består af 4 kernemoduler, en række valgmoduler samt selvorganiserede projektmoduler, et projektmodul og et afsluttende masterprojektmodul. Som studerende kan man vælge at tage uddannelsen i kronologisk rækkefølge på den normerede tid, 2 år, som deltidsstuderende, man kan vælge et enkelt modul i vilkårlig rækkefølge, eller tage hele uddannelsen på et år som fuldtidsstuderende. Hovedparten tager uddannelsen på 2 år. Standarden er, at hvert modul starter med et fysisk 3 dags seminar på et af de deltagende universiteter. Modulerne fortsætter og afsluttes virtuelt. Virtuelle aktiviteter varierer fra asynkrone diskussioner, blogs, projektaktiviteter orkestreret i MIL's Moodle miljø til synkrone præsentationer, diskussioner og vejledning via video/ og eller lyd baserede teknologier som Adobe Connect, Skype eller Google+.

Uddannelsen er tværfaglig, projekt og problemorienteret. Det grundlæggende didaktiske design har fokus på en dialogorienteret og diskussionsbaseret tilgang byggende på en socialkonstruktivistisk ontologi. (Dirckinck-Holmfeld, Jones, \& Lindström, 2009; Andreasen \& Nielsen, 2013). Undervisningsteamet repræsenterer de samarbejdende universiteter og således en tværfaglig og tværdisciplinær tilgang til forskningsfeltet Tilgangen og fortolkningen af projekt og Problem-baseret læring varierer dog i tråd med de 4 universiteters forskellige undervisningskulturer og pædagogiske fortolkninger af PBL. På uddannelsen ser man dette som en særlig mangfoldig mulighed for at demonstrere og præsentere forskellige pædagogiske variationer gennem forskelligt tilrettelagte kurser. Dog er det overordnede fælles filosofisk/pædagogiske afsæt for MIL Computer Supported Collaborativ Learning (CSCL) og Distance Education (DE) og har konkret et mål om at skabe rum for refleksion, meningsforhandling og læring gennem digital demokratisk dialog (Sorensen, 2009), hvor kollaboration om fælles projekter er det centrale (Dillenbourg, Järvelä, \& Fischer, 2009).

For at stilladsere de virtuelle-dialoger, er der i det didaktiske design meget faste rammer for arbejdsgang og krav til de studerende. Der er kvantitative mål for mængden af skriftlige debatindlæg og de enkelte gruppemedlemmer gives roller som henholdsvis fremsætter, opponent og moderator samtidig med, at alle kan kommentere andre gruppers indlæg 
En væsentlig forskel mellem de valgte cases er, at MIL fra sin begyndelse er designet som en BL uddannelse. Grundlæggerne var bevidste om udfordringer og muligheder og var stærkt inspirerede af CSCL (Sorensen \& Murchú, 2006; Sorensen, 2009).

De to cases fra UCN tager i modsætning hertil afsæt i en eksisterende uddannelse, der er redesignet fra tilstedeværelsesuddannelse til BL forløb, med den forskel at forandringen i radiografuddannelsen er baseret på nogle års erfaringer med BL forløb. Alligevel har de 3 cases en del ligheder og fælles udfordringer. Det er disse vi i det følgende vil redegøre for. Alle cases er funderet i en socialkonstruktivistisk læringsforståelse, hvor det at interagere i netværk og arbejde kollaborativt er en grundlæggende betingelse. Læring konstrueres sammen med medstuderende gennem peer-to-peer feedback både i synkrone og asynkrone forløb, som indgår i det didaktiske design. Alle cases undersøger og anvender ligeledes nye sociale og digitale samarbejdsværktøjer og netværkstjenester

\section{Analyse og fortolkning}

Analyserne af det empiriske materiale er genereret fra fokusgruppeinterviewene med henholdsvis de lærerstuderende (LS) de radiografstuderende (RS) og de masterstuderende (MS). Den analytiske strukturering er grundlaget for fortolkning, hvor anden viden er taget $\mathrm{i}$ anvendelse for at belyse den empirinære analyse med et bredere forståelsesgrundlag. Fortolkningen er struktureret omkring temaer genereret på baggrund af fokusgruppeinterviewene:

- Fællesskabet,

- Lærerroller

- It kompetencer (lærer/stud).

Fortolkningen inddrager teori og forskningsresultater fra anden forskning med henblik på at skabe en distancerende optik. Det giver et grundlag for sammenligning og differens og bidrager dermed til en nuanceret forståelse af både de empiriske fund og den eksisterende viden om engagerende designs.

\section{Tema 1: Fællesskabet}

Fællesskabet er et centralt tema, som går igen igennem alle fokusgruppeinterviews. Fællesskabet vedrører både de virtuelle og fysiske rum. Der er fundet to dimensioner af fællesskabet, som har betydning for de studerenderes engagement. Der er den sociale relationelle dimension og den faglige læringsmæssige dimension. Begge dimensioner er dog tæt sammenvævede, omend der er foretaget en analytisk skelnen her. 


\title{
Den sociale relationelle dimension
}

De studerende på radiografuddannelsen gør brug af de sociale medier til at holde kontakten til hinanden, når de er i praksis, og dermed fungerer denne kommunikation som virtuel forbindelse til de sociale fysisk etablerede relationer fra UCN.

\begin{abstract}
"Det er hyggeligt nok (at kommunikere virtuelt), hvis man ikke ser hinanden i lang tid og mens vi har været i praktik, så kan man stadigvæk lige sende en sms eller... Vi har sådan en gruppe inde på Facebook, den er lige oprettet, så kan vi skrive, hvis der er..." (RS)
\end{abstract}

De studerendes orientering i praktikken kan således understøttes af den teknologiske dimension og dermed den adgang, de sociale medier giver $\mathrm{i}$ relation til den interpersonelle dimension. Dette tyder på, at de studerende selvinitieret, og uden problemer, navigerer på velkendte sociale medier og anvender mediet som understøttende fagligt og socialt supplement til praktikken.

MIL er en efter- og videreuddannelse, og masterstuderende (MS) er typisk allerede i en professionel relation. De synes, ligesom de UCN studerende, meget bevidste om, at det at have sociale relationer til sine medstuderende har betydning for engagement i studiet. En studerende fortælle om, at han netop af den grund kom i god tid til første seminar

"... så jeg havde set dette som en mulighed for at prøve at sammen med nogen - altså få et studieliv igen, det er jo mange år siden, jeg er en gl. mand jo, så jeg havde faktisk bevidst valgt at komme op i god tid for simpelthen at kunne gå rundt og sprede god stemning" (MS)

Den gode sociale relation er vigtig for samarbejdet. Dette kommer til udtryk i følgende citat, hvor en MIL studerende fortæller om, på hvilket grundlag han fandt sammen med sin projekt makker:

"Det var absolut ud fra, at vi ville skrive projekt sammen, så måtte vi finde ud af, hvad vi ville skrive om bagefter, det var der ikke nogen tvivl om" (MS)....

Og videre....

"så er der god energi og god humor og så tænkte jeg, så bliver det jo sjovt at studere, for det er jo hårdt og det er mange timer, så det skal også være skægt" (MS) 
En anden siger om gruppedannelse:

"Men der er det der helt personlige i, at vi komplementerer hinanden, vi har samme arbejdsmoral og samme tilgang til, at det her, det er vigtig i vores liv" (MS)

"Erfaringer fra MIL har vist, at det at have fysiske sociale arrangementer er vigtigt. Derfor lægges der på weekendseminarerne vægt på god tid til socialt samvær. Den fysiske kontakt har vist sig at være befordrende for den efterfølgende virtuelle kontakt, såvel under selve uddannelsesforløbet som efter endt uddannelse.

Den faglige læringsmæssige dimension

Radiografstuderende vurderer de sociale forpligtelser som essentielle for deres engagement, men de kobler primært det sociale fællesskab til det fysiske rum, hvor de får mulighed for at sætte ord på faglig viden og forhandle denne. De sociale fællesskaber fungerer således som faglige responsrum og som engagerende fora:

"Det er man vant til (at mødes fysisk). Det er nemmere at diskutere noget. Jeg tror, vi alle sammen helst vil mødes (fysisk). Det er bare noget med at få diskuteret tingene igennem, så man får sagt det højt” (RS)

De lærerstuderende udtrykker samstemmende, at det sociale faglige fællesskab har en betydning i forhold til deres engagement i studiet, da det indebærer en forpligtende struktur, som ikke i samme grad gør sig gældende i virtuelle aktiviteter. Én udtrykker det således:

“Når man først kommer op på skolen, så er du tvunget til at gøre... Det betyder meget, det sociale sammenhold, hvor den gode læring kan finde sted. Man har brug for at connecte - også til underviserne. Så vil man hellere komme herop og få det her nærvær, man får bare ikke det samme ud af det som hvis man sidder alene... Jeg synes det er så fedt når man sidder og diskuterer noget på en gruppe og så lige pludselig, så er der bare noget, der går op for en. Det er bare den fedeste følelse i verden. Ja, og det der med, man kan blive sådan helt høj, når man finder på en god idé og man siger fuck (stille sagt)... (LS)

Italesættelsen af, hvorledes fagligheden understøttes og genereres gennem diskussioner i fællesskabet tegner et billede af, at både vidensnetværk, fagfæller og omgivelser indgår i en større kompleksitet, hvilket også understøttes af Rennie \& Morrison (2013). Den faglige sociale dimension udtrykkes af de studerende under indflydelse af følelser, som f.eks. "den 
fedeste følelse" og "man kan blive helt høj”. Ligeledes er dimensionen under indflydelse af interaktionen i fællesskabet udtrykt som "Ja, når man lige connecter" og strukturen, der her er bestemt af gruppearbejdsformen, samt spatialiteten, som er illustreret ved at man sidder ned sammen i det fysiske rum. Disse former for indflydelse er nærmere beskrevet i relation til de læerestuderendes orientering i blendede læringsrum (Dau, 2015).

Digitale medier anvendes også direkte i relation til løsning af fælles opgaver, hvor systemerne giver nogle fordele i forhold til at kommunikere sammen skriftligt, mens de er sammen fysisk og samtidigt har mulighed for at diskutere analogt verbalt: "Altså, vi bruger jo meget nettet... platforme som Titan Pad og Google Drev til at lave vores ting på, men det er som regel hvor vi sidder og er fysisk tilstede... sidder ved 4 computere og så skriver sammen, det er sådan vi bruger det". (LS)

Online-rummet anvendes også som socialt understøttende læringsnetværk. Det sociale medie Facebook fungerer som kommunikationsrum for det sociale fagfællesskab:

"Ja, men det har vi jo brugt meget Facebook til, hvor folk har f.eks. den der danskopgave... var der noget med en eller anden slutning, der skulle analyseres?... Og folk havde alle mulige idéer til hvordan den skulle analyseres. Lige kommunikere med de andre og høre, hvad tænker I, ikke sidde helt alene med det" (LS)

Citatet illustrerer, hvorledes teknologibrugen, ressourcerne og infrastrukturen har indflydelse på gruppens virtuelle aktivitet f.eks. i relation til arbejdet i Facebook og Google Drev. Disse resultater stemmer overens med Glud et al.'s (2010) fund af elementer af betydning for meningsfuld undervisningstilrettelæggelse, men i relation til citatet ovenfor er det de studerende selv, som er de designerne af mulighederne for gensidige feedback.

At kunne lære af hinanden er også væsentlig for de MIL studerende. MIL studerende er typisk personer, der er i fuldtidsarbejde og ønsker at kvalificere sig inden for anvendelse af ikt i deres praksis. Ofte har de været alene om ikt dimensionen på deres arbejdsplads og ønsker at kunne være i dialog med ligesindede og dermed opbygge et fagligt fællesskab, hvor ikt er en dominerende faktor i læring, udvikling og implementering. Ved dannelse af projektgrupper på MIL, har det betydning, at man kan lære af hinanden og har forskellige kompetencer repræsenteret i gruppen, således siger de studerende

"Det drejer sig om, at NN (medstuderende) har så mange kvaliteter, som jeg kan lære rigtig meget af, både ift at strukturere, være akademisk og have et vidensoverblik" (MS) 
Og en anden:

"I mit arbejdsliv kan jeg sidde i nogle situationer, som jeg er vældig ene om, så jeg havde set dette som en mulighed for at prøve at - være sammen med nogen... jeg gik i hver tilfælde efter en social dimension i det" (MS)

Og videre:

"Jeg har nogle meget ensomme opgaver på arbejde og havde brug for at møde nogen, ikke nødvendigvis man er ens med, men man kunne være sammen med i dette læringsfællesskab." (MS)

Én udtrykker, hvorledes han ikke kun søger et fagligt fællesskab, men også et socialt studenterfælleskab.

"Oftest i forbindelse med videndeling, inspiration eller jobmuligheder. Vi er ofte i kontakt. Vidensdeling omkring beslægtede undervisnings- og forskningsområder. Hvis jeg i arbejdsmæssig sammenhæng havde brug for nogle samarbejdspartnere med de kompetencer eller jobs, mine tidligere medstuderende har. Personlige relationer". (MS)

De sociale fællesskaber viser sig både i professions- og masteruddannelsesregi at være et fundament for såvel engagementet som læringen i de nævnte BL forløb. Generelt er det sociale fællesskab et grundlag for relationer og skabelse af rum for en tryg identitetsdannelse, hvilket også Henderson (2007) fremhæver. Især i professionsuddannelser synes fællesskab at have en signifikant rolle i forhold til den kommende professionelle fagudøvelse, da denne også vedrører at blive dannet til en profession og have et fagfællesskab, som kan understøtte den professionelle udøvelse i praksis. Derudover er både lærer- og radiografuddannelsen relations professioner, hvilket vil sige at relationen til patienter/elever er et centralt element i professionsudøvelse. Både studiemæssigt og i professionerne er fællesskabet et forpligtende socialt engagement, som understøtter den faglige udvikling under Bl forløbene (Dau, 2015).

\section{Tema 2: Underviserroller:}

Underviserens ageren og rolle i designprocessen er et andet tema, som viser sig i alle fokusgruppeinterviewene. Der er forskellige dimensioner heraf. Der er den vejledende og retningsvisende dimension, samt engagementsdimensionen og holdningsdimensionen. Begge dimensioner er dog tæt sammenvævede, omend der er foretaget en analytisk skelnen her. På tværs af dimensionerne er synlighed et centralt element. 


\section{Den vejledende og retningsvisende dimension}

Fælles for LS og MS er, at de især i det første halve år savnede, at det didaktiske design, var mere tydelig og retningsgivende. Det var uklart, hvad der kvantitativt blev forventet af dem i relation til de ikt-medierede opgaver og studieaktiviteter. De studerende oplevede uklare mål og rammer. Ligeledes vurderede de, at underviserne ikke havde tilstrækkeligt kendskab til, hvilke didaktiske medier, der kunne anvendes og hvordan. De oplevede derfor, at de blev frustrerede, når de selv skulle håndtere web 2.0 teknologien til egen formidling:

"Jeg ved nogle af de opgaver, jeg har lavet i min tidligere studiegruppe, det... Altså, de var jo ikke prangende, fordi at vi ikke sådan fik ordentlig vejledning ... fordi at det ikke har lykkedes, og problemet har nok været, at vores lærere ikke har kommunikeret gennem medier. Det er svært hvis læreren ikke 'skærer det ud i pap, hvad det er han/hun mener, der skal laves i opgaven" (LS)

De lærerstuderende oplevede de blendede forløb i læreruddannelsen, som meget opsplittede. Især det første år, hvor det primært var én underviser, som stod for de virtuelle forløb og de øvrige undervisere for de fysisk tilstedeværelsesforløb. Det betød, at de studerende savnede det fysiske kendskab til underviseren bag de virtuelle forløb, og de havde svært ved at se meningen med disse.

"Fordi vi ikke forstod hvad det var vi sku'... Jeg synes, det var åndsvagt et eller andet sted" (LS).

Ligeledes blev de tilsyneladende påvirkede af, at nogle af deres undervisere i det fysiske rum, havde stærke præferencer for tilstedeværelsesundervisning.

"Lige nu kan jeg ikke helt se meningen med det. Og helt klart, hvis der var en lærer, som bare var: 'Det er det fedeste i hele Verden', så smitter det også af på os, så ville vi også gøre det meget mere. Så jeg tror det handler om, at få de rigtige undervisere ud til det" (LS)

Iblandt de radiografstuderende var guidning og en tydelig rammesætning og struktur også oplevet som et centralt element for deres studieaktiviteter, og didaktiske understøttende strukturer blev værdsat. Ligesom hos de lærerstuderende blev betydningen af den rigitige (gode) underviser fremhævet blandt de radiografstuderende:

"Så man har brug for en eller anden form for guidning til, hvad det er man skal - en vejviser. Ja, for ellers så sidder du bare 
fuldstændig blank og fatter ikke, hvad det er, det hele går ud på. Men hun virker også som den eneste, der virkelig har sat sig ind $\mathrm{i}$ det (streamet undervisning), der kunne finde ud af det, projekt har vi kamera og her har vi fokus, så kører vi bare, og bare stil” (RS)

Masterstuderende efterlyser også en tydeligere stilladsering. Her beskrives, hvorledes underviseren kommer på banen efter en del forvirring om opgaven

"Så kom NN (underviseren) ind som en synlig moderator og bakkede op omkring det, så stoppede vi op og begyndte ligesom forfra, det handlede om, at vi skulle afdannes. Os med den lange akademiske skole fik en over næsen og alle dem, der sad og ikke sagde noget, de fik også en, så på den måde ligger der noget dannelse, så det var sådan en erkendt erkendelse.... Man kan scaffolde dem (underforstået de studerende) noget mere... det har jeg tænkt - kunne man gennem et skarpere forventningsdesign få det samme frem..." (MS)

Underviserens rolle, engagement, synlighed, feedback, retningsgiven og itkompetence er således helt afgørende for studerendes motivation og orientering i studiet. Underviserens rolle og fremtoning synes at have en smittende effekt på studerende og deres vilje til at deltage. I lighed med Kemps (2013) fund er der generelt tegn på, at interaktionen mellem undervisere og studerende, samt underviserens retningsgivning og vejledning, har stor betydning for de studerendes tilfredshed.

\section{Engagementsdimensionen og holdningsdimensionen}

I lighed med underviserrollen og underviserens tilgang og holdning så har studerendes tilgang og åbenhed overfor designet også indflydelse på engagement. Undervisernes bidrag til integrering af virtuelle undervisningsmidler og deres positive holdning hertil synes at have en afsmittende effekt på de lærerstuderendes engagement, hvilket blev fortalt således:

"Jeg synes de (underviserne) har en super kreativ tilgang. Og jeg har aldrig haft så, så varieret og så fed en undervisning. Det fanger mig rigtig meget... fordi jeg har mulighed for at udfolde mig kreativt frem for at sidde stille på min pind hele dagen. Vi har bare fået en masse ideer omkring, hvordan man underviser og sådan noget, men vi har jo lært en rigtig masse, vi har bare, ja, vi har været i den der idéernes verden" (LS)

De studerendes holdning til undervisningsformen og deres oplevelse af, at den bidrager til deres egen læring og kreativitet, synes således at være en 
afspejling af, hvorledes engagementet er faciliteret af den varierede undervisningstilrettelæggelse og den måde som underviserne har engageret sig og åbnet for kreative designs og nye idéer.

\section{Tema 3: It kompetencer}

It-kompetencer er som de øvrige temaer et centralt element i relation til engagerende didaktiske design. Dette vedrører ikke kun underviserens itkompetencer, men også de studerendes. Der knytter sig to dimensioner til itkompetencer; en mestringsdimension og en refleksionsdimension. Begge dimensioner er dog tæt sammenvævede, omend der i lighed med de foregående analyser, er foretaget en analytisk skelnen her.

\section{Mestringsdimensionen}

De lærerstuderendes mestring i relation til tilegnelse af it-kompetencer synes stærkt knyttet til muligheden for omsættelse til lærergerningen. Lærerstuderende er motiverede for tilegnelsen af it-kompetencer, når det giver mening i relation til deres egen didaktiske tilrettelæggelse af undervisning i folkeskolen. Én udtrykte det således:

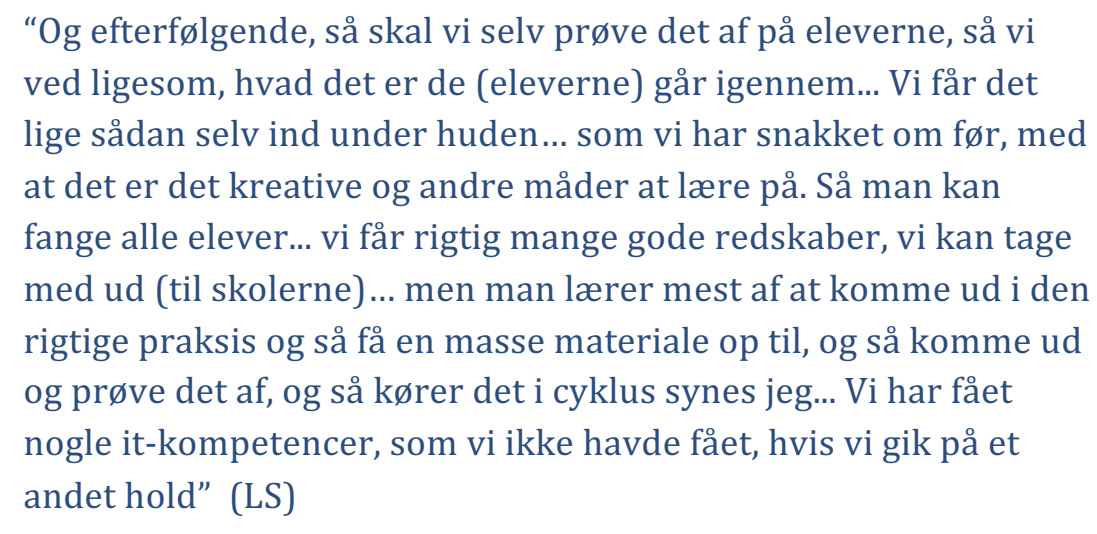

Citatet ovenfor pointerer, hvorledes praksisverden og overførbarhed bliver centralt for de studerendes engagement $\mathrm{i}$ at mestre de blendede undervisningsformer og de teknologiske muligheder.

Nogle MIL studerende oplever, at der er store forskelle mellem de studerendes it-kompetencer og mestring. Dette kan være en barriere i gruppearbejdet, da nogle gruppemedlemmer bruger tiden på at lære fra sig $\mathrm{i}$ stedet for at diskutere og afprøve teknologiernes potentialer

"Der var også et stort gab imellem teknisk viden og ret meget tid blev så brugt til at oplære vore 2 gruppemedlemmer i teknologier, som vi egentlig tog for givet, og som vi var kommet for at prøve kræfter med" (MS) 
Mestingen af teknologien bliver afgørende for såvel uddannelsesdeltagelsen som anvendelsen i praksis. Praksisnærheden bekræftes af (Bleiker, Knapp, \& Frampton, 2011) og mestingen af teknologien som afgørende faktor viser sig netop i studier af barrierer herfor, f.eks. i relation til problemer med at navigere i de virtuelle læringsmiljøerne (John-Matthews, Gibbs, \& Messer, 2013; Dau 2015).

\section{Refleksionsdimensionen}

Refleksion er en central del af UCNs læringstilgang. De studerende reflekterer eksempelvis over deres brug af de virtuelle studierum og læringsplatforme derhjemme og det mix, der pågår mellem formel og uformel læring på de sociale medier:

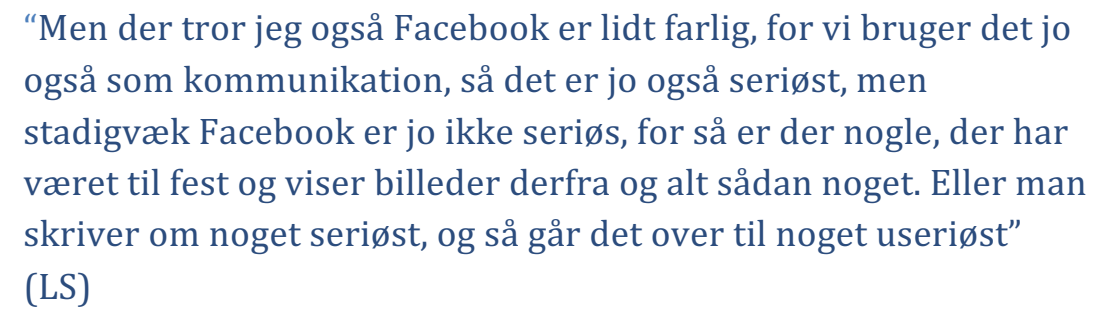

Citatet afspejler, hvordan kendte medier tages i anvendelse til kommunikation omkring studierelevant arbejde, men også hvilke udfordringer dette giver. Det afspejler endvidere studerendes refleksioner over deres navigationsvanskeligheder mellem formelle og uformelle læringsrum når de agerer i de virtuelle læringsrum. Dette taler derudover for en remediering af læreprocesserne når de overføres til et virtuelt læringsrum (Zemsky og Massy 2005, s. 248)

\section{Resultater}

Undervisere og studerendes engagement og fællesskabsfølelse spiller en central rolle for udøvelse og udvikling af professionernes kerneydelser. Derfor får fællesskabet også en afgørende rolle i relation til de studerende, som er deltagere i didaktisk designede blendede forløb. Betoningen af fælleskabet og engagementet i uddannelserne synes således at være afgørende for successen af implementeringen af de didaktiske designs.

Det empiriske materiale bekræfter, at der er flere væsentlige forhold, som gør sig gældende, når vi ser på den del af undervisningscyklus, som handler om forholdet mellem designet og engagementet med og mellem studerende. Engagementet bliver faciliteret af fællesskabet både i det fysiske og i det virtuelle læringsrum, og hver del synes at understøtte den anden del, som det f.eks. viste sig ved de studerendes brug af sociale medier til at bevare kontakten til medstuderende, når de var i praktik eller tilbage på jobbet. Denne gensidige effekt af forskellige typer af fællesskabsrum indeholder både en interpersonel dimension omkring de sociale netværk, en 
refleksionsdimension relateret til personernes læring og holdning og en teknologisk dimension som mulighedsrum, hvilket er i overensstemmelse med Wozniak, Lever \& Pizzicas (2009) fund.

De 3 temaer og de dertil hørende dimensioner præciserer yderligere, hvorledes fællesskabet har indflydelse på studerendes engagement. Herunder, hvorledes fællesskabet både har en social relationel funktion og en faglig læringsmæssig funktion. Dette viser sig især ved, at fællesskabet er både forpligtende og fagligt understøttende for de studerendes engagement, hvad enten der er tale om gruppefællesskaber, praksisfællesskaber eller holdfællesskaber af virtuel eller fysisk karakter. Underviseren er også en central person og hans/hendes rolle som fagligt engageret, faciliterende, vejvisende og motiverende moderator er af højeste betydning for de studerendes deltagelse i det faglige undervisningsfælleskab og graden af engagement heri. Derudover har de studerendes holdning til de blendede undervisningsformer en central betydning for det engagement, som udspiller sig. Underviserens eget engagement får afsmittende betydning for de studerendes engagement. Endelige har de studerendes og undervisernes itkompetencer er grundlæggende betydning for graden af engagement $\mathrm{i}$ blendede forløb, og engagementet er her påvirket af underviserens og de studerendes mestring af brugen af blendede læringsrum, samt af den refleksion der koblers hertil.

Praksisrelevansen og overførbarhed til praksis synes at være det meningsgivende element i de studerendes tilegnelse af it-kompetencer.

I relation til det didaktiske design bliver følgende elementer vigtige:

- Afdækning af deltagerforudsætninger og holdninger hos undervisere og studerende

- Udvælgelse af engagerende it-kompetente underviser, som finder designet relevant

- Understøttelse af it-kompetenceudvikling hos studerende og undervisere

- Tilrettelæggelse af studiegruppearbejde i fysiske og virtuelle miljøer

- Tydelig rammesætning af forløb

- Stilladsering af de studerende

- Anvendelse af metoder, der har relevans for praksis

- Tilrettelæggelse af retningsgivende vejledning og feedback 


\section{Diskussion og konklusion}

BL er ikke en læringstilgang, men et didaktisk anliggende i virtuelle og fysiske miljøer. Successen hermed er bestemt af de studerendes og undervisernes engagement, og hvorledes dette understøttes gennem fællesskabende aktiviteter, hvilket i sidste ende har direkte indflydelse på både adgangen til viden, deling af viden, anvendelse af viden samt udvikling og overførsel af viden. Da resultaterne baserer sig på et begrænset datagrundlag hentet fra 3 uddannelsesforløb, kan det være svært at generalisere fundene til en bred målgruppe. Når vi alligevel finder det relevant at sige noget konkret om designs, skyldes det den generiske karakter, som gives i form af data fra fokusgruppeinterviewene. Den økologiske optik afspejler en kompleksitet af både læringsrummenes affordance, underviserens rolle og samspillet med fagfæller.

Det primære fokus for design af blendede læringsmiljøer indenfor professionsuddannelser, efter videreuddannelser og masteruddannelser indebærer i relation til fundene en gentænkning af designs, herunder betydning af praksisrelevansen og udvikling af it-kompetencer til håndtering af de af samfundet stillede kompetencekrav.

Dalziels (2003) argumenterer for:

"Learning Design has the potential to revolutionize e-learning by capturing the "process" of education, rather than simply content" (Dalziel 2003: 593)

Vi har afprøvet denne påstand ved at sætte vores cases ind i den foreslåede Learning Design ramme (fig 1). Vi er enige i, at den facilitere refleksioner over pædagogisk filosofi og metode, men i herværende artikel, hvor vi primært interesserer os for det didaktiske design, har vi fokuseret på de fysiske og virtuelle relationers potentialer for læring med fokus på sustainability inden for learning design. Vi har således anvendt et økologisk perspektiv på det empiriske materiale, som afspejler, hvorledes faciliterende fællesskaber og synliggørelse af identiteter er befordrende for de studerendes øgede engagement i læreprocessen. Dermed tilbyder vi en fornyet læringsoptik på BL. I lighed med Rennie \& Morrison (2013) adresserer vi en kompleksitet og fokuserer på både læringsmiljøer og læringsaktører. I højere grad end tilfældet er i Dalziel et al.'s Learning Design fremhæver vi det engagerende fællesskab, som en central og afgørende del i undervisningscyklussen.

\section{Referencer}

Andreasen, L. B., \& Nielsen, J. L. (2013). Educational designs supporting student engagement through networked project studies. Increasing Student Engagement and Retention Using Mobile Applications: Smartphones, Skype and Texting Technologies, 19-46. 
Bleiker, J., Knapp, K. M., \& Frampton, I. (2011). Teaching patient care to students: a blended learning approach in radiography education. Radiography, 17(3), 235-240.

Borgmann, A. (2010). Reality and technology. Cambridge Journal of Economics, 34(1), 27-35.

Chew, E., Jones, N., \& Turner, D. (2008). Critical review of the blended learning models based on Maslow's and Vygotsky's educational theory. In International Conference on Hybrid Learning and Education (pp. 4053). Springer.

Christensen, B. (2014). FlexVid og praksistilknytningen. In C. H. Jensen \& H. J. Staugaard (Eds), FlexVidere (pp.37-47). Book on Demand Aalborg: UCN Forskning og Udvikling

Dalziel, J. (2003). Implementing learning design: The learning activity management system (LAMS). In G.Crisp, D.Thiele, I.Scholten, S.Barker and J.Baron (Eds), Interact, Integrate, Impact: Proceedings of the 20th Annual Conference of the Australasian Society for Computers in Learning in Tertiary Education. Adelaide, 7-10 December 2003.

Dalziel, J. (2013). Implementing learning design: A decade of lessons learned. Electric Dreams. Proceedings Ascilite, 210-220.

Dalziel, J., Conole, G., Wills, S., Walker, S., Bennett, S., Dobozy, E., ... Bower, M. (2016). The Larnaca declaration on learning design. Journal of Interactive Media in Education, 2016(1).

Dau, S. (2015). Studerendes orientering i fleksible professionsuddannelsers læringsrum: Et narrativt casestudie af vidensudviklingens veje og afveje. Videnbasen for Aalborg UniversitetVBN, Aalborg UniversitetAalborg University, Det Humanistiske FakultetThe Faculty of Humanities, Elearning labE-learning lab.

Dillenbourg, P., Järvelä, S., \& Fischer, F. (2009). The evolution of research on computer-supported collaborative learning. In Technology-enhanced learning (pp. 3-19). Springer.

Dirckinck-Holmfeld, L., Jones, C., \& Lindström, B. (2009). Analysing networked learning practices in higher education and continuing professional development. Sense Publishers.

Egekvist, C. T., Nyrup, C. H., Sloth, H. Thomsen, H., Debess, J. E., VejleSørensen, J. C.,... Hansen, S. H. (2012). Model for de sundhedsfaglige uddannelser med udgangspunkt i radiografuddannelsen. In C. H. Jensen \& H. J. Staugaard (Eds), FlexVid: Fleksible arbejdsformer i videregående uddannelser (pp. 101-126). Book on Demand Aalborg: UCN Forskning og Udvikling

Florer, T. (2013). A study of student engagement and the factors that contribute to students' use of blended learning technologies. 
Garrison, D. R., \& Kanuka, H. (2004). Blended learning: Uncovering its transformative potential in higher education. The Internet and Higher Education, 7(2), 95-105.

Garrison, D. R., \& Vaughan, N. D. (2008). Blended learning in higher education: Framework, principles, and guidelines. John Wiley \& Sons.

Glud, L. N., Buus, L., Ryberg, T., Georgsen, M., \& Davidsen, J. (2010). Contributing to a learning methodology for web 2.0 learning-Identifying central tensions in educational use of web 2.0 technologies. In Proceedings of the 7th International Conference on Networked Learning (Vol. 2010, pp. 934-94).

Graham, C. R. (2006). Blended learning systems. The Handbook of Blended Learning, 3-21.

Gynther, K. (2014). Uddannelsesteknologi og didaktisk design for det 21. århundrede.

Harasim, L. (2012). Learning theory and online technologies. Routledge.

Henderson, M. J. (2007). Investigating the role of community in sustaining teacher participation in blended professional development. James Cook University.

Hiim, H., \& Hippe, E. (2007). Læring gennem oplevelse, forståelse og handling: en studiebog i didaktik (Vol. 2. udgave). [Kbh.]: Gyldendal.

Illeris, K. (2011). Kompetence. Samfundslitteratur.

John-Matthews, J. S., Gibbs, V., \& Messer, S. (2013). Extending the role of technology enhanced learning within an undergraduate radiography programme. Radiography, 19(1), 67-72.

Jokinen, P., \& Mikkonen, I. (2013). Teachers' experiences of teaching in a blended learning environment. Nurse Education in Practice, 13(6), 524528.

Kemp, L. J. (2013). Introducing blended learning: An experience of uncertainty for students in the United Arab Emirates. Research in Learning Technology, 21.

Kolmos, A., Fink, F. K., \& Krogh, L. (2004). The Aalborg PBL model. Aalborg University Press Aalborg.

Launsø, L., Rieper, O., \& Olsen, L. (2011). Forskning om og med mennesker: forskningstyper og forskningsmetoder i samfundsforskning. København: Nyt Nordisk Forlag.

Laurillard, D. (2008). Technology enhanced learning as a tool for pedagogical innovation. Journal of Philosophy of Education, 42(3-4), 521-533.

Laurillard, D. (2013). Teaching as a design science: Building pedagogical patterns for learning and technology. Routledge. 
Masika, R., \& Jones, J. (2016). Building student belonging and engagement: insights into higher education students' experiences of participating and learning together. Teaching in Higher Education, 21(2), 138-150.

Master i IKT og Læring. (2016). Retrieved 19 August 2016, from http://www.aau.dk/uddannelser/efteruddannelse/master/ikt-laering

Matzat, U. (2013). Do blended virtual learning communities enhance teachers' professional development more than purely virtual ones? A large scale empirical comparison. Computers \& Education, 60(1), 40-51.

Motteram, G. (2006). 'Blended'education and the transformation of teachers: a long-term case study in postgraduate UK Higher Education. British Journal of Educational Technology, 37(1), 17-30.

OECD. (2016). AN OECD HORIZON SCAN OF MEGATRENDS AND TECHNOLOGY TRENDS IN THE CONTEXT OF FUTURE RESEARCH POLICY. København: Danish Agency for Science, Technology and Innovation. Retrieved from http://ufm.dk/en/publications/2016/files/an-oecd-horizon-scan-ofmegatrends-and-technology-trends-in-the-context-of-future-researchpolicy.pdf

Oliver, M., \& Trigwell, K. (2005). Can 'blended learning'be redeemed? ELearning and Digital Media, 2(1), 17-26.

Piki, A. (2011). Learner Engagement in Computer-Supported Collaborative Learning Environments: A mixed-methods study in postgraduate education. University of London.

Rennie, F., \& Morrison, T. (2013). E-learning and social networking handbook: Resources for higher education. Routledge.

Rogers, Y., Sharp, H., \& Preece, J. (2011). Interaction design. Wiley, Chichester.

Ryberg, T., \& Dau, S. (2013). Sociale medier i klinisk praksis. In Læring i og af klinisk praksis. Nyt Nordisk Forlag Arnold Busck.

Santandreu Calonge, D., Chiu, P., Thadani, D. R., Mark, K. P., \& Pun, C. F. (2011). In-service development for graduate teaching assistants: A blended-learning and formative approach. Journal of University Teaching \& Learning Practice, 8(3), 3.

Sharpe, R., \& Beetham, H. (2010). Understanding students' uses of technology for learning: towards creative appropriation. Rethinking Learning for the Digital Age: How Learners Shape Their Experiences, 85-99.

Smyth, S., Houghton, C., Cooney, A., \& Casey, D. (2012). Students' experiences of blended learning across a range of postgraduate programmes. Nurse Education Today, 32(4), 464-468.

Sorensen, E. K. (2009). Undervisning og læring på tværs af fysiske og medierede rum: Et case studie på universitetsniveau. In Vidensmedier. 
Sorensen, E. K., \& Murchú, D. Ó. (2006). Enhancing Learning Through Technology. IGI GLOBAL

Staugaard, H.J. (2012). Blended Learning - et spørgsmål om økologi. In C. H. Jensen \& H. J. Staugaard (Eds), FlexVid: Fleksible arbejdsformer i videregående uddannelser (pp. 22-38). Book on Demand Aalborg: UCN Forskning og Udvikling

Tørnæs, U. (2016). Behov for bedre match mellem uddannelse og job Uddannelses- og Forskningsministeriet. Retrieved 18 August 2016, from http://ufm.dk/minister-og-ministerium/ministeren/taler/2016/behovfor-bedre-match-mellem-uddannelse-ogjob?searchterm=fleksible $\% 250 \mathrm{~A} \% 20 \% 20 \% 20 \% 20 \% 20 \% 20 \% 20 \% 20 \%$ $20 \% 20 \% 20 \% 20 \% 20 \% 20 \% 20$ uddannelser

Wozniak, H., Mahony, M. J., Lever, T., \& Pizzica, J. (2009). Stepping through the orientation looking glass: A staged approach for postgraduate students. Australasian Journal of Educational Technology, 25(2), 221234.

Zemsky, R., \& Massey, W. F. (2005). Stalled: E-learning as thwarted innovation. Global Perspectives on E-Learning: Rhetoric and Reality, 241-255. 